\title{
Public-Private Partnership: A Path for Green Tourism Certification Egypt as a case study
}

\author{
Nashwa Mohamed Talaat \\ Tourism Studies department \\ Faculty of Tourism and Hotel Management \\ Sadat City University
}

\begin{abstract}
Tourism sustainable development is important to the growth of any destination and more so for Egypt, one of the fastest growing in the world. To overcome the shortage of infrastructure against a growing demand for tourism, large investments are required. But the shortage of funds in the public sector often hinders development projects. Green star hotel initiative was the first of its kind with private sector to overcome this difficulty. Public-Private Partnership (PPP) aims to build strong collaboration between the Government and private sectors in the tourism industry. The purpose of this paper is to shed light on the role of PPP in greening the tourism industry by presenting a case study for a PPP project that has been implemented in Egypt in the tourism sector. It will also identify and analyze a new path for tourism development -public-private partnership, and underscore the advantages deriving from this type of partnership, through the assessment of the effectiveness of such a project in encouraging green tourism in Egypt.
\end{abstract}

Keywords: Public Private Partnership, Sustainable Tourism, Green Tourism, Green Certification, Egypt

\section{Introduction}

A public-private partnership (PPP) refers to "arrangements, typically medium to long term, between the public and private sectors whereby some of the services that fall under the responsibilities of the public sector are provided by the private sector, with clear agreement on shared objectives for delivery of public infrastructure and/or public services"(world Bank, n.d). This term has been widely used to express any cooperation between governmental and private sector. This cooperation includes any kind of projects based on a contract between the government and private business (CNN, 2010). There are several reasons for establishing such a partnership. The most important one is transferring the know-how and financial strength from private business to public ones. The European Union considers public private partnership projects as anti crises tool projects (Țigu et al., 2008).

\section{Advantages of public-private partnership}

- The Investor makes an agreement with the Administrative Authority under the PPP law apart from the traditional law and its regulations.

- The foreign investor is well protected: for instance, his approval is required to amend the contractual conditions and the administration cannot amend the fixed prices by its own

- Egypt modified its rules for public private partnerships (PPP) to allow clashes to be resolved through negotiation rather than through courts. Under the new rule, negotiations would be carried out at the Cairo International Arbitration Centre and based on the regulations of the United Nations Commission on International Trade Law (UNCITRAL) (Galal, 2012)

\section{Public-private partnership in tourism industry}

Tourism industry includes several forms of associations that provide tourist service some of these need huge investments. That's why public private partnership can be useful in such projects. Public-private partnerships target tourism infrastructure of a region, because this kind of projects needs enormous investments.

It exists in two phases of the life cycle of a resort at its start, when essential integrated development plans of the whole region, in this phase the local authority must ensure sustainable development for the stable growth of the community. Meanwhile, the private sector is interested in increasing returns. The second time is when it is suitable to create a new period of growth to create a resort with a constant flow without large seasonal fluctuations (Weiermaier et al., 2008). Public Private Partnership projects were encouraged by the UNWTO as a means of stimulating revival of the travel and tourism sector during the 2008/9 global economic crisis (CNN, 2010). 


\section{Implementation of PPP's in green tourism certification}

The Green Star Hotel Initiative (GSHI) started in 2007 to enhance the environmental performance and to improve competitiveness of the Egyptian hotel industry. This was done by encouraging the implementation of environmental management systems and environmentally friendly practices. The partners in the Egyptian and German tourism industry started to work together within a PPP programme that the Deutsche Gesellschaft für internationale Zusammenarbeit (GIZ) implements on behalf of the German Federal Ministry for Economic Cooperation and Development (BMZ) with ministry of tourism. The Private sector partners are: Travco Group, the leading tour operator in Egypt, Orascom Hotels and Development, one of the leading hotel investment companies in the Middle East and TUI AG the European leading tour operator and investment group Company; AGEG Consultants as technical experts (The Challenge-Sustainable Tourism Development in Egypt, n.d)

Project Partners

PPP - Partnership Project

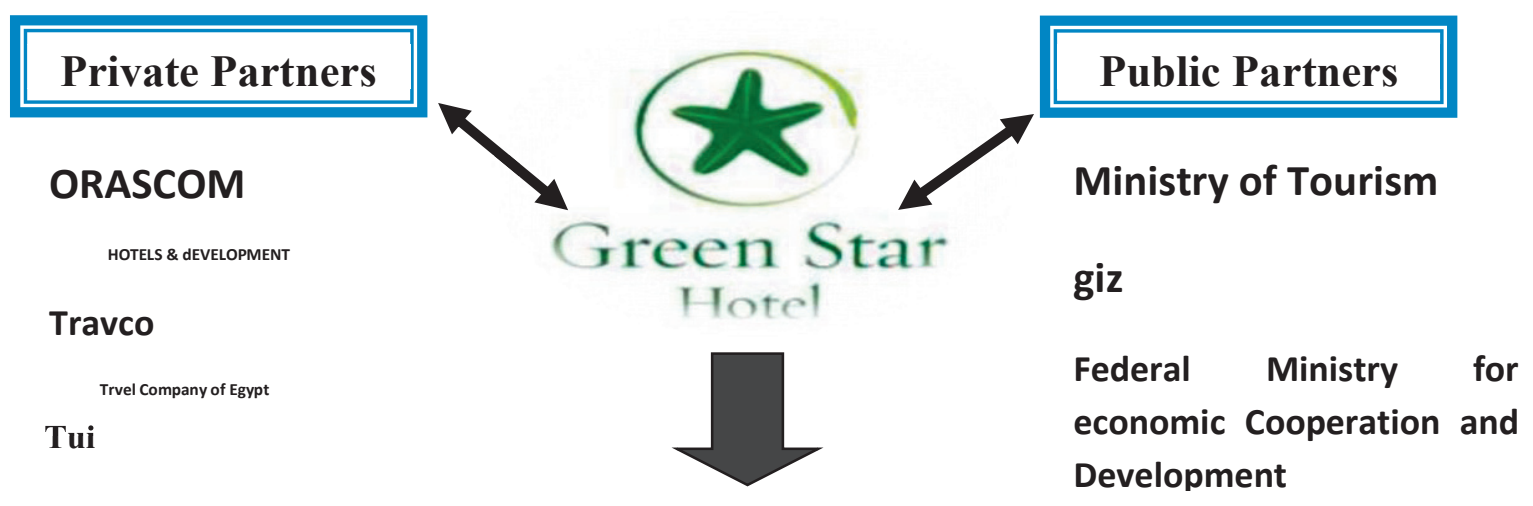

\section{Improvement of the environmental performance and competitiveness of the Egyptian hotel industry}

Figure (1): the Green Star Hotel Initiative, Source: (Fritz, 2010)

The Green Star Hotel Initiative is the first national eco certification system and capacity building programme in the middle east- the same as Austrian Eco Label, Eco Label Luxemburg, Nordic Swan, Scandinavia Legambiente Turismo, Italy, Steinbock Suiss Eco Label, Green Tourism Business Scheme; and Great Britain, Ireland. The objective of the Green Star Hotel Initiative is to enhance the environmental performance and support the competitiveness of the Egyptian Hotel Industry. One of its objectives also is to encourage all hotels to get the Green Star Hotel certification through a more environmentally-friendly attitude as well as the improvement of their image in front of the international guests. The aim of the Green Star Hotel Initiative is to have a deep impact on tourism destinations development in Egypt by motivating the hotel sector to become more sustainable, leading other tourism sectors to the way of sustainability. The hotel sector, started to change all its activities into green ones to make Egypt a sustainable destination through (Zaazou, 2013):

- Significant reduction of water, energy and chemical consumption (up to 30\%),

- Increased use of renewable energy (up to $25 \%$ ),

- Reduction of waste accumulation (up to $20 \%$ ) and proper waste handling,

- Awareness raising among hotel staff and guests,

- Capacity building for sustainable hotel management

\section{Logo description}

The Green Star Hotel label is first created for El Gouna as pilot destination (The green star hotel initiative, n.d). It is a Star fish that stands for the sea and coral reefs as major Egyptian tourist attractions. The Green color stands for nature and environment and reflects environmental consciousness. The 'Green Star Hotel' name was chosen because Green is a common and a well-known element in eco-labels' names (e.g. Green Globe, Green Key) and the Star refers to starfish symbol as well as the star hotel accreditation system (fritz, 2010). 
Green Star Hotel Criteria (Fritz, 2010)

- $\quad$ Based on the Global Sustainable Tourism Criteria (GSTC)

- Benchmarks for water and electricity consumption

- A set of 151 sustainability criteria including all operational areas of the hotel from which 10 are obligatory:

\begin{tabular}{|l|l|l|}
\hline 1 & Environmental Management & 13 \\
\hline 2 & Training \& Instructions & 3 \\
\hline 3 & Water & 22 \\
\hline 4 & Energy & 27 \\
\hline 5 & Waste & 13 \\
\hline 6 & Guest Information & 12 \\
\hline 7 & F\&B, Kitchen & 14 \\
\hline 8 & Housekeeping & 20 \\
\hline 9 & Garden and Beach Area & 14 \\
\hline 10 & Interior and Exterior Appearance & 13 \\
\hline
\end{tabular}

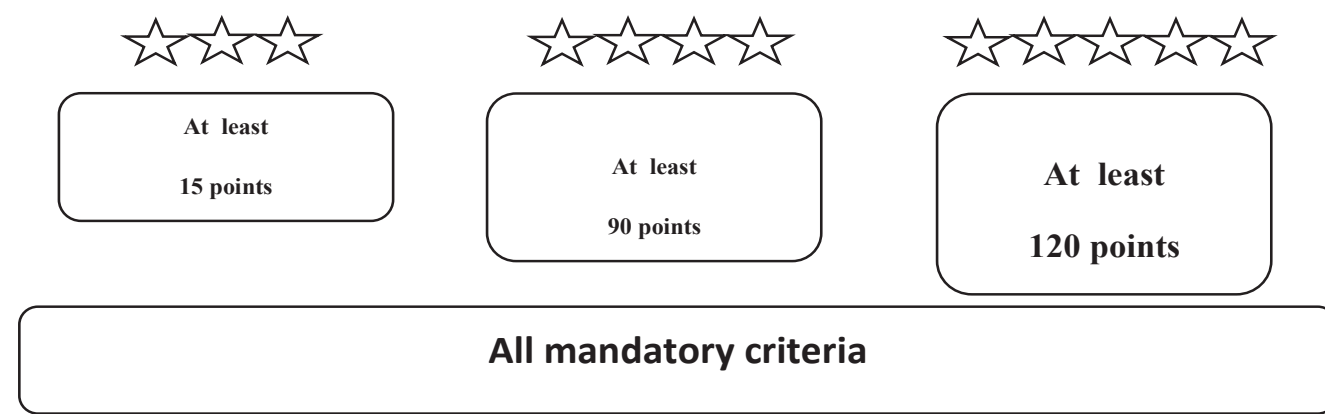

Figure (2): Key Criteria for Environmental Performance, Source (Fritz, 2010)

To receive the Green Star hotel certificate, the hotel needs to accomplish ten environmental (mandatory) key criteria (Zaazou, 2013) which are:

1. The hotels fulfill with local zoning, natural and cultural heritage requirements

2. Environmental management system implemented:

- Water, energy and chemical consumption, documented and monitored

- Green Team assigned, responsibilities defined

- Environmental policy established

- Action plan developed

3. Environmental staff training organized and assured

- In house training provided at least every three month

- Environmental staff instructions are posted in the departments and

- Included in the job descriptions

4. Daily documentation of water consumption and treatment of waste water is assured

- All waste water and grey water is treated. No open sewage.

- At least $75 \%$ of all gardens, sports facilities and outdoors are irrigated by recycling water.

- Water saving devices in more than $50 \%$ of the guest rooms are installed, water flow in the $100 \%$ of the guest rooms are less than 8 liters/per minute - Benchmarks achieved 
5. Energy saving measures is implemented and consumption is monitored and documented

- At least $60 \%$ are energy saving bulbs

- Automatic key card system implemented

- Benchmark achieved: guest night less than $55 \mathrm{kWh}$

- Optional: Use of renewable energies

6. Waste is properly treated, waste accumulation avoided

- Waste is separated and treated according to local or national waste management facilities

- At least two recycling practices are implemented - plastic bags are avoided

- No use of disposable one way products like cups, plates and cutlery except in pool areas

7. Environmental guest information is displayed

8. Use of cleaning agents and chemicals is reduced; consumption documented and monitored

9. Sustainable purchase policy implemented

10. Sustainable operation practices for the garden and beach areas are implemented

Once the hotel is ready to be certified, the process usually consists of paying a fee to the certifier, filling in a series of documents and questionnaires, and an evaluation by an auditor or some other mechanism of determining fulfillment. After the hotel is certified, the process does not stop. It will be expected to maintain the high standards that allowed the hotel to be certified.

\section{Success factors of the Green Star Hotel System}

The Green Star Hotel system is very special, and what makes it very special and successful is that it is tailored for the local conditions of the region. It is also based on the Global Sustainable Tourism Criteria (GSTC) taking into account the local climatic characteristics and infrastructure. The criteria of The Green Star Hotel were developed and supplemented with measurable indicators and benchmarks (Zaazou, 2013).

Certification process is very important because it sets standards and helps to differentiate real sustainable tourism businesses from others. This helps to protect the honesty of these concepts. Certification is not the final objective. It is a tool for motivating businesses and others to improve their environmental, social, and economic performance, while rewarding them for doing so. These rewards are sometimes tangible and sometimes not.

\section{Benefits of certification}

There are several benefits for green tourism certification for certified business, consumers, government and also for environment which is presented in the following table

Table (1): Benefits of certification

\begin{tabular}{|l|l|l|l|}
\hline $\begin{array}{l}\text { Benefits for certified } \\
\text { businesses }\end{array}$ & $\begin{array}{l}\text { Benefits for } \\
\text { consumers }\end{array}$ & $\begin{array}{l}\text { Benefits for } \\
\text { governments }\end{array}$ & $\begin{array}{l}\text { Benefits for the } \\
\text { environment and local } \\
\text { communities }\end{array}$ \\
\hline $\begin{array}{l}\text { Certification helps } \\
\text { businesses to improve } \\
\text { themselves: going through } \\
\text { a certification process is } \\
\text { educational. Many } \\
\text { certified businesses have } \\
\text { stated that one of the } \\
\text { greatest benefits of the } \\
\text { certification process was } \\
\text { to teach them the elements } \\
\text { of sustainability in their } \\
\text { operations and focus their } \\
\text { attention on the changes } \\
\text { they needed to make in } \\
\text { their businesses. A better- }\end{array}$ & $\begin{array}{l}\text { Certification provides } \\
\text { environmentally and } \\
\text { socially responsible } \\
\text { choices, it helps } \\
\text { consumers to know } \\
\text { which businesses are } \\
\text { truly socially and } \\
\text { environmentally } \\
\text { responsible and to } \\
\text { make choices on this } \\
\text { basis. As certification } \\
\text { programs become } \\
\text { better known, this may } \\
\text { produce tangible }\end{array}$ & $\begin{array}{l}\text { Certification helps } \\
\text { povernments } \\
\text { niches market as } \\
\text { ecotourism } \\
\text { destinations, } \\
\text { especially when } \\
\text { the credibility of } \\
\text { the destination is } \\
\text { threatened by } \\
\text { green washing. }\end{array}$ & $\begin{array}{l}\text { environment and do little } \\
\text { or no damage to it. }\end{array}$ \\
\hline
\end{tabular}


Public-Private Partnership: A Path for Green Tourism Certification

\begin{tabular}{|c|c|c|c|}
\hline $\begin{array}{l}\text { operating business tends } \\
\text { to be more efficient and to } \\
\text { attract more clients. }\end{array}$ & $\begin{array}{l}\text { benefits in a business's } \\
\text { reputation and } \\
\text { popularity. }\end{array}$ & & \\
\hline $\begin{array}{l}\text { Certification tends to } \\
\text { reduce operating costs. } \\
\text { This has been found in } \\
\text { almost every type of } \\
\text { business certification. }\end{array}$ & $\begin{array}{l}\text { Certification in general } \\
\text { increases public } \\
\text { awareness of } \\
\text { responsible business } \\
\text { practices. }\end{array}$ & $\begin{array}{l}\text { Certification } \\
\text { raises industry } \\
\text { standards in } \\
\text { health, safety, } \\
\text { environment, and } \\
\text { social stability. } \\
\end{array}$ & $\begin{array}{l}\text { It requires businesses to } \\
\text { respect local culture and } \\
\text { provide real economic } \\
\text { and social benefits for it. }\end{array}$ \\
\hline $\begin{array}{l}\text { The process of } \\
\text { implementing certification } \\
\text { of sustainable tourism is } \\
\text { often accompanied by } \\
\text { easier access to technical } \\
\text { assistance and financing } \\
\text { for businesses to } \\
\text { implement new } \\
\text { technology }\end{array}$ & $\begin{array}{l}\text { Certification can alert } \\
\text { tourists to the } \\
\text { environmental and } \\
\text { social issues in an area, } \\
\text { allowing them to act } \\
\text { more respectfully or } \\
\text { contribute to solutions. }\end{array}$ & $\begin{array}{l}\text { It lowers the } \\
\text { regulatory costs } \\
\text { of environmental } \\
\text { protection. }\end{array}$ & $\begin{array}{l}\text { When the business is } \\
\text { economically sustainable, } \\
\text { and offers quality of } \\
\text { service to ensure that, it is } \\
\text { likely to continue offering } \\
\text { benefits for the long term. }\end{array}$ \\
\hline $\begin{array}{l}\text { Potentially, certification } \\
\text { can provide a marketing } \\
\text { advantage to certified } \\
\text { businesses, as consumers } \\
\text { learn to recognize credible } \\
\text { certification brands. This } \\
\text { has happened in other } \\
\text { industries, such as organic } \\
\text { foods, wood products, } \\
\text { clothing, wine, etc. }\end{array}$ & $\begin{array}{l}\text { Certified businesses } \\
\text { tend to offer better } \\
\text { quality service. }\end{array}$ & $\begin{array}{l}\text { By requiring } \\
\text { economic benefits } \\
\text { to communities, } \\
\text { certification can } \\
\text { help reduce } \\
\text { poverty. }\end{array}$ & \\
\hline
\end{tabular}

Source: Centre for Eco-Tourism and Sustainable Development, n.d

\section{Methodology}

This paper investigates the opinion of 14 green star certified hotels in El-Gouna destination. El-Gouna considered a pilot destination in implementing the green star hotel certification. Questionnaire has been distributed on top managers who are directly involved in strategic decisions of the sample hotels. The survey aims to measure knowledge about PPP projects and evaluate the effectiveness and success of that certification; this was done through using five point Likert scale. 11 hotels only responded to the interviews.

\section{Results}

By analyzing the answers using SPSS as shown in table 2, the following results were identified. The general mean for the answers of the questions is 4.09 and the standard deviation is 0.202 . This indicates that there is a large acceptance to the statements of the questions. Respondents agreed that without having a green star hotel initiative project, it would be difficult to adopt a green transformation (mean 5.000). Come in the second rank, respondents asserted that having the green star hotel certificate increased hotel's competitive advantage and market share (mean 4.909 and standard deviation 0.3015). The results, also, emphases that having the green star hotel certificate increases the income of hotels (mean 4.182 and standard deviation 0.4045 ). In addition it was asserted that the green transformation was supported by the local authority, in terms of taking a major volume of risk (mean 4.000 and standard deviation 0.6325). Finally, implementation of the green star hotel initiative found to need a continuous extra load on the hotel which in turn needs extra investments (mean 2.455 and standard deviation 0.934). This implies that this statement was refused by respondents.

Table (2): descriptive analysis

\begin{tabular}{|l|c|c|c|}
\hline \multicolumn{1}{|c|}{ Statement } & Mean & Std. Deviation & Sig. P. value \\
\hline $\begin{array}{l}\text { having the green star hotel certificate } \\
\text { increased the hotels competitive advantage } \\
\text { and market share }\end{array}$ & 4.909 & 0.3015 & 0.004 \\
\hline $\begin{array}{l}\text { implementation of the green star hotel } \\
\text { initiative will need a continuous extra load on } \\
\text { the hotel that needs extra investments }\end{array}$ & 2.455 & 0.934 & 0.419 \\
\hline the green transformation was supported by the & 4.000 & 0.6325 & 0.215 \\
\hline
\end{tabular}




\begin{tabular}{|l|c|c|c|}
\hline $\begin{array}{l}\text { local authority, in terms of taking a major } \\
\text { volume of risk }\end{array}$ & & & \\
\hline $\begin{array}{l}\text { having the green star hotel certificate } \\
\text { increases the income of the hotels }\end{array}$ & 4.182 & 0.4045 & 0.010 \\
\hline $\begin{array}{l}\text { without having a green star hotel initiative } \\
\text { project it would have been very difficult for } \\
\text { the hotel to make the green transformation }\end{array}$ & 5.000 & 0.000 & --- \\
\hline Total & 0.20226 & 4.0909 & \\
\hline
\end{tabular}

For the open question on top managers' opinion about the PPP, it was concluded that most respondents consider the public-private partnership as a form of association which manages a private sector project. The latter is financed through local budget, under certain conditions negotiated before. Another kind of partnership that respondents regard as ideal is financed by structural funds for development. And because these are more attractive, they require less investment than projects developed in private partnerships. Another aspect that emerged from the feedback received is the senior management's need for European funded projects, due to more stringent criteria in terms of implementation.

\section{Conclusion}

The main conclusion that emerges from that research is shedding light on the importance of the public-private partnership for sustainable tourism development in Egypt. This development will be achieved through getting the private sector with public authorities on certain conditions that must be met by local authority, in terms of taking a major volume of risk. The public-private partnership (PPP) project played an important and vital role in the green transformation in Egypt. It created a certifying body that provides the first national eco label in the Middle East. The certified hotels increased its market share and competitive advantage; it also increased its income, without having a continuous extra load and investments on the hotel. It is important that tourism sector try different strategies to adapt tourism products they offer, forced by reduction of the tourist traffic, but also the changing preferences of tourists in which the environmental awareness is highly increasing. Thus a major local development plan is needed, to attract foreign tourists, but this involves a promotional activity, which implies high costs for each provider separately but in a financial partnership efforts will be lower. European funds are another attraction for the private sector, as projects funded from this budget are monitored and thus require high performance criteria; the project will ensure a higher quality level.

\section{References}

Centre for eco-tourism and sustainable development, (n.d) A Simple User's Guide To Certification For Sustainable Tourism And Ecotourism 3rd Edition. Available online from: http://idbdocs.iadb.org/wsdocs/getdocument.aspx?docnum=1028822 last accessed 3/3/2014

CNN, (2010) PPP - Partnering for Tourism growth, Available online from http://www.cnnmediainfo.com/task/download/TASK_Compass_19.pdf last accessed 2/3/2014

Fritz,B. (2010) Green Star Hotel Initiative Phase II 2009 - 2012

Available on line from http://www.giz.de/expertise/downloads/en-tourism-reisepavillon-2010destinationsentwicklung-fritz-ageg.pdf last accessed 2/3/2014

Galal, A. ( 2012) Highlights on Public Private Partnership in Egypt, Available online from http://lexarabiae.meyerreumann.com/issues/2012-2/vol-xvi-issue-4-oct-2012-articles/highlights-on-public-private-partnership-in-egypt last accessed on $2 / 3 / 2014$

The green star hotel initiative (n.d) available online from http://www.elgouna.com/pdf/green-star-factsheet.pdf last accessed on $2 / 3 / 2014$

The Challenge Sustainable Tourism Development in Egypt, (n.d) Available online from: http://www.greenstarhotel.org/?page_id=8 last accessed on 2/3/2014

Țigu,G., Bogdan,G., Bulin, D. (2008) Public-Private Partnership a new path for tourism development, Academy of Economic Studies, Bucharest, Available online from http://www.academia.edu/2386259/PublicPrivate_Partnership___a_new_path_for_tourism_development last accessed on 2/3/2014

Weiermaier K., Peters M., Frehse J. (2008) Success Factors For Public Private Partnership: Cases In Alpine Tourism Development, Journal of Services Research, Special Issue (February, 2008).

World Bank (n.d) Public private partnership, Available online from (http://PPP.worldbank.org/public-privatepartnership/overview/what-are-public-private-partnerships) last accessed on 2/10/2014. 
Zaazou, H. (2013) Green Growth in the Egyptian Tourism Sector, Berlin Available online from http://www.itbberlin.de/media/global/global_image/global_apps/global_edb/global_edb_upload_2013/global_edb _events_itbk_1/edb_261701.pdf last accessed 2/3/2014.

$$
\text { الشر اكة بين القطاعين العام و الخاص: مسار للحصول على شهادة السياحة الخضراء }
$$

التنمية السياحة المستدامة أمر بالغ الأهمية لنمو أي مقصد سياحى و خاصه مصر حيث انها تعتبر واحدة من أسرع المناطق نموا في العالم.

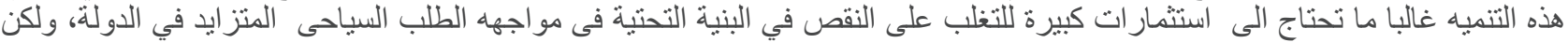

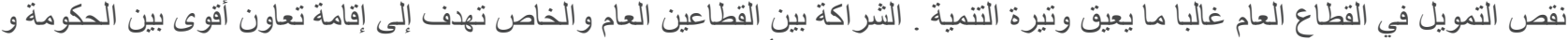

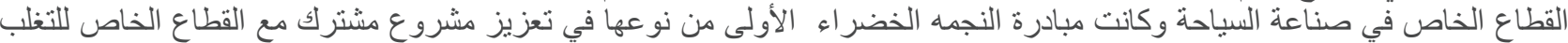

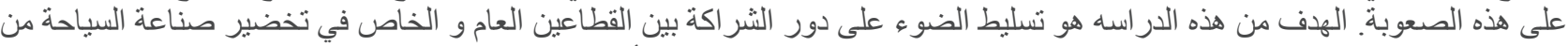

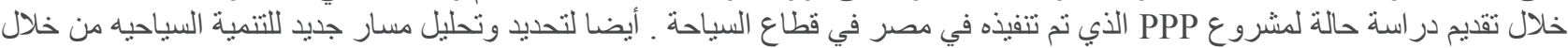

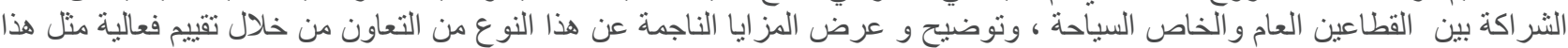
المشروع في الحفاظ على السياحة الخضر اء في مصر. 